\title{
Facilities Management-Future Prospect in Malaysia
}

\author{
Mariah Awang ${ }^{\mathrm{a}}$, Abd. Hakim Mohammed ${ }^{\mathrm{b}}$, Mohd Norizam Md. Sallehc, Nur Hafizah Joharid ${ }^{\mathrm{d}}$, Nurhayati Khair ${ }^{\mathrm{d}}$ \\ ${ }^{a}$ Fakulti Teknologi Kejuruteraan Awam, Universiti Tun Hussein Onn Malaysia, 86400 Parit Raja, Malaysia \\ ${ }^{b}$ Fakulti Geoinformasi dan Harta Tanah, Universiti Teknologi Malaysia, 81310 UTM Johor Bahru,Johor, Malaysia \\ ${ }^{c}$ Fakulti Kejuruteraan., Universiti Putra Malaysia, 43300 Serdang, Malaysia \\ ${ }^{d}$ Fakulti Perakaunan dan Pengurusan, Universiti Tunku Abdul Rahman, Malaysia
}

*Corresponding author: mariah@uthm.edu.my

\begin{abstract}
The concept of facilities management were introduced in Malaysia since mid-90s with its aim was to ensure national own facilities are functioning well and to reach its maximum life time. Nevertheless 20 years had passed not much development since then. This claim is proven factual, as the root cause for some problems or incident happen such as buildings and ceilings collapsed, roofs or roof leaking and cracking on bridges were lead to the failure to carry out the facility management systems. Although the Government is now seen taking a move more aggressively in enhancing facility management, but obviously our country is still lagging with other practitioners. In this regard, this article aims to provide a deeper understanding for the Organisation and individual on the importance of facility management within an organisation in producing high-income organisation in line with the $10^{\text {th }}$ Malaysia Plan to feature Malaysia into high-income developed countries.
\end{abstract}

Keywords: Facility Management; Malaysia

Abstrak

Konsep pengurusan fasiliti telah diperkenalkan di Malaysia sejak dari pertengahan 90-an bertujuan untuk memastikan fasiliti milik negara dapat berfungsi dengan baik dan mencapai jangka hayat yang maksimum. Walau bagaimanapun setelah lebih 20 tahun berlalu, tidak banyak perkembangan yang dikecapi sejak itu. Kenyataan ini terbukti benar, kerana penyebab utama terhadap beberapa permasalahan atau insiden yang berlaku seperti bangunan dan siling runtuh, bumbung atau atap bocor dan keretakan kepada jambatan adalah terarah kepada kegagalan untuk melaksanakan sistem pengurusan fasiliti. Meskipun kerajaan pada hari ini dilihat mengambil langkah yang lebih agresif di dalam meningkatkan pengurusan fasiliti, tetapi negara kita masih ketinggalan berbanding negara-negara yang lain. Justeru, artikel ini bertujuan untuk memberikan pemahaman yang lebih mendalam kepada organisasi dan individu peri pentingnya pengurusan fasiliti dalam organisasi ke arah menghasilkan organisasi berpendapatan tinggi selari dengan Rancangan Malaysia ke-10 untuk menempatkan Malaysia dalam kalangan negara-negara maju yang berpendapatan tinggi.

Kata Kunci: Pengurusan Fasiliti; Malaysia

(C) 2017 Penerbit UTM Press. All rights reserved

\subsection{INTRODUCTION}

As a developing country, Malaysia has to compete among the other developing countries in attracting foreign investors. Competition not only in providing good economic environment and attractions but also in offering good and acceptable infrastructures. Based on this awareness, the Government through its five-year Malaysia development plan from the first Malaysia Plan till the $9^{\text {th }}$ Malaysian plan has allocated a sum of RM 415 billion or $60 \%$ of the total provisions were focused on the development of physical infrastructure (Shaziman, 2009).

Each of this infrastructure and facility provided or developed necessarily requires good care, repair and proper maintenances to keep them effective, workable form and efficient. That is why facility management is very essential in order to ensure all facilities provided are able to function as expected with efficient cost. However in general facility management in Malaysia is still backwards compared to developed countries such as Japan, New Zealand, Australia, Singapore and Hong Kong. These countries have a facility management system covering a wider field of building management, services and associated workforce in supporting the strategic objectives of the Organisation (Shahrul \& Emma, 2010). Back in Malaysia, facility management is often associated with building maintenance. This article discusses the literature related to the purpose and topic of study. The discussions include literature in connection with the facility, facility management, facility management chronology, the importance of facility management and facility management implementation initiatives in Malaysia which is the footing for this study. Each infrastructure and facilities provided or developed necessarily requires good care, repair and maintenance in order for them to works effectively and efficiently. 


\subsection{FACILITY}

Generally facility management can be construed as a kind of public facilities. It describes the physical facilities and services provided for a specific site. According to Dewan Bahasa dan Pustaka, Malaysia Dictionary (2005) facility is something easy or routine work and from Oxford Dictionary (2005) defines facility as being designed, created, designed, and installed to provide the service. There are various definition about facility and partially they were stated in Table 1.

Table 1 Definitions of facility

\begin{tabular}{|c|c|c|}
\hline No. & $\begin{array}{c}\text { Sources } \\
\end{array}$ & $\begin{array}{c}\text { Definition } \\
\end{array}$ \\
\hline 1 & $\begin{array}{l}\text { Town and country planning act } 1976 \\
\text { (Commissioner of Law Revision Malaysia (2006) }\end{array}$ & $\begin{array}{l}\text { Facility is any quality or state of a place or area that also led to the area becoming } \\
\text { fun, harmony, and can be benefited better. }\end{array}$ \\
\hline 2 & Cleland and Kerener (1985) & $\begin{array}{l}\text { Facility as a physical instrument, including property and any changes that may } \\
\text { increase in value, including building and equipment, intended to simplify and help } \\
\text { functions. }\end{array}$ \\
\hline 3 & Alexander (1993) & $\begin{array}{l}\text { Facility is the premises needed by the organisation to equip and facilitate their } \\
\text { core activities. }\end{array}$ \\
\hline 4 & A project Management Dictionary of Terms (1995) & $\begin{array}{l}\text { Facility as a physical-shaped tools including real estate and any changes that } \\
\text { could increase the value to it, including buildings and equipment, which means } \\
\text { facilitate and assist the level it's operational. }\end{array}$ \\
\hline 5 & Hishamuddin (2005) & $\begin{array}{l}\text { Facility is not only limited to facilities or physical facilities, but it also includes } \\
\text { aspects of the service. }\end{array}$ \\
\hline
\end{tabular}

Students are always looking at facilities provided by a college/university as one of their main factor in selecting a place to further their study (Price et al., 2003). Facilities can also be an added business value to an organisations. As a result of the stated definition, it can be said that anything provided for the convenience of the users can be called as facility. To an organisation, facilities are infrastructures that supports individuals in an organisation in carrying out his/her work so in achieving the main goal of the business or organisation in Jamie (2007) opinion is the same facility as non-core services, which refers to the buildings and services.

\subsection{FACILITY MANAGEMENT}

\section{Definition of Facility Management}

The efforts to define facility management in Malaysia can not escape from looking at the definitions that have been produced in the countries that practices this discipline much earlier. For example in the United States, International Facility Management Associate (IFMA), defines facility management as a profession that encompasses a variety of disciplines to ensure functionality of the environment built by integrating people, place, processes and technology (IFMA, 2010). The definition of facility management in continental Europe which were among the countries that actively participate in the practice facility management discipline is the United Kingdom, France and Germany were also soughed. In the United Kingdom, British Institute of facility management or better known as the British Institute of Facilities Management (BIFM), defines facility management is a compilation of multidisciplinary activities in environment and management that affect the people and the workplace (BIFM, 2010). People is covers employees, consumers, customers and external as well as visitors. The workplace covers all physical and non-physical element within a building or premises (Abdul et al., 2006).

Subsequently the Center for facility management or Centre for Facilities Management (CFM) at the University of Strathclyde, United Kingdom (1995), which is one of the earliest institutions of higher learning degree programme facility management in the country classified facility management is the process, whereby organisations provide and maintain a quality working environment and provide quality support services to achieve the objectives of the organisation at the best cost. Facility management provides focus on organisational effectiveness to manage facilities and services to users and customers as a whole. Facility management is a process that involves planning, implementation, maintenance and control of an account to something physical space and services for an organisation as well as costs associated in managing its operations (Hammer, 1988). Table 2 shows some definition on facility management by authors especially researchers, academician or facilities management practitioner.

Table 2 Definitions of facilities management

\begin{tabular}{ll}
\hline \multicolumn{1}{c}{ Authors } & \multicolumn{1}{c}{ Definitions } \\
\hline Hamer (1988) & $\begin{array}{l}\text { Facility management as the process of planning, implementation, maintenance, accounting for } \\
\text { physical space and services in accordance with an organisation, and at the same time looking for } \\
\text { ways to reduce the costs associated } \\
\text { Facility management is the management of all company services not limited to business core } \\
\text { activities but including building management, data management, catering, security and } \\
\text { distribution. }\end{array}$ \\
Henly Centre (1991) & $\begin{array}{l}\text { Facility management is a process when the organisation members and maintain support services } \\
\text { in a quality environment by using appropriate cost to meet the needs of an organisation. }\end{array}$ \\
Quah (1998) & $\begin{array}{l}\text { Facility management includes financial management, space management, operations } \\
\text { management and user management for an organisation }\end{array}$ \\
Springer (2001) & $\begin{array}{l}\text { Facility management is a combination of various professions including the principles and theory } \\
\text { of engineering, architects, design, financial management and of human science. } \\
\text { Facility management as an integrated approach to maintaining, improving and adapting the }\end{array}$
\end{tabular}


Pitt \& Tucker (2008)

Kamaruzzaman \& Zawawi, (2010)

IFMA (2010)

BIFM (2010) building, creating a supportive environment the main objectives of the organisation. Facility management is the integration and alignment of non-core services, including those related to place, needed to operate and maintain a business to fully support the primary purpose of the organisation.

Facility management is a balance between technical and business management that may be related with the processes of making strategic decisions.

Facility management is a profession that encompasses a variety of disciplines to ensure functionality of the environment built by integrating people, place, processes and technology Facility management is the process of integration in the Organisation to preserve and develop the approved service support and enhance the effectiveness of the main activities.

From the various definitions that have been specified, its' concluded that the relationship between facilities and facility management is a combination of various activities between employees, processes and work place that supports the operations of an organisation. Alexander (1996) has formulated a number of parameters should play their role in order for facility management in an organisation to achieve its functions and objectives. The aspects of the policy are the provision of facilities related to the corporate value of the organisation, authorisation to facility management unit to improve the quality of services an organisation, develop facilities for achieving goals and objectives of the organisation management, and recognition of the added value of the facility management organisation.

\section{The Role of Facility Management}

Hammer (1985) stated that the role of facility management includes organisational management, facility planning, budget, procurement and identify economic factors include property and disposal. In addition, he also entered management factor rental, design and planning of engineering and architecture, maintenance areas, buildings, to financial management and security. While Alexander (1996) felt that sets out the functions of an organisation acting as the Manager and the controller and is responsible for all the facilities and services offered to meet the needs and requirements of users and customers as facility management. Ahmed Losekoot (2002) referred, "Effective Facilities Management" as a good practice guide in maintaining facilities and had listed some of the main role of the facility management as below;

- real Estate Management,

- financial management,

- $\quad$ organisational management,

- change management and innovation, and

- $\quad$ human resource management.

In the same year Okoroh et al. (2002) also have determined six main role of facility management, for which there is a slight difference from Losekoot, namely:

- management of physical assets,

- consideration of physical assets or linkages humans,

- use of contractors,

- information technology Management

- identify core and non-core activities to achieve optimum management for both, and

- $\quad$ strategic management for facilities.

From the literatures, there are varieties of opinion about the role of facility management and even if five facilities managers being asked with regard to the role of facility management, it will be very difficult to get two similar answer. Referring to IFMA, Springer (2001) had classified facility management roles and responsibilities as tabulated in Table 3.

Table 3 Classification roles and responsibilities of facility management (IFMA, 2010)

\begin{tabular}{cll}
\hline No. & \multicolumn{1}{c}{ Classification Roles } & \multicolumn{1}{c}{ Facility Management Responsibilities } \\
\hline 1 & Maintenance Operation & Furniture Maintenance \\
& & Finishes Maintenance \\
& & Preventive Maintenance \\
& Breakdown Maintenance \\
& & Exterior Maintenance \\
$\mathbf{2}$ & Administration Service & Custodial / house-keeping \\
& & Landscape Maintenance \\
& & Corporate Artwork \\
& & Mail Services \\
& & Shipping / Receiving \\
& & Records Retention \\
3 & Space Maintenance & Security \\
& & Telecommunications \\
& & Copy services \\
& & Space inventory \\
& Space policies \\
& & Space allocation \\
& & Forecasting needs \\
& & Furniture specifications \\
\end{tabular}




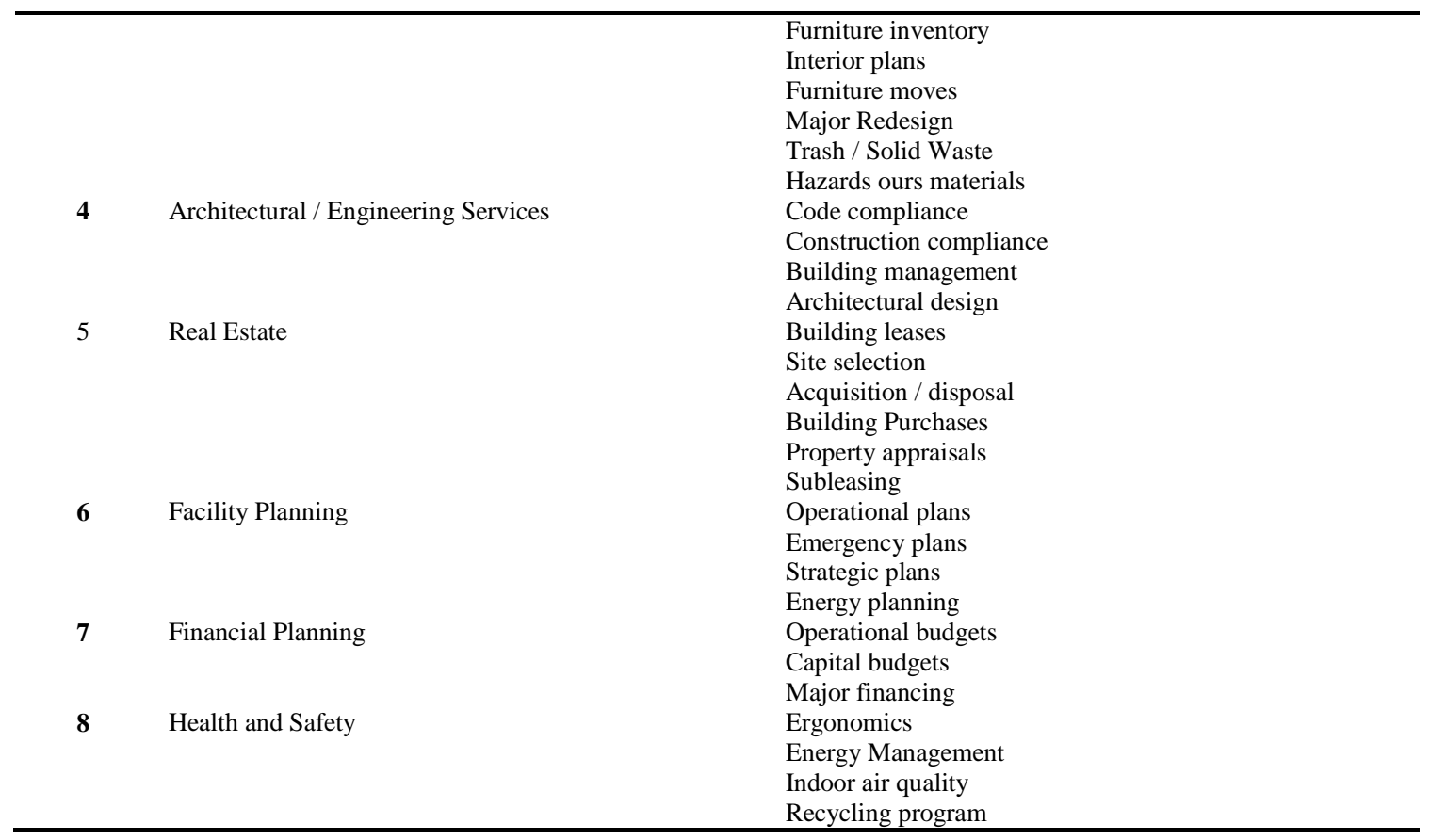

However, Chotipanich (2004) has listed the roles and responsibilities of the facility management within the scope of support services which can be given to facility manager. Roles and responsibilities listed by him are as in Figure 1 . Table 2 and Figure 1 demostrate that facility management provides the scope of services is very wide and found there are many responsibilities of the facility manager but is still there some duplication between each other. It is clearly shown that the facility manager role must be identified in accordance with the organisation and appropriateness of the scope of work in the organisation. This role is important to ensure the process of implementation and monitoring run smoothly.

Meanwhile, the study of the IFMA Foundation (2001) in the U.S.A and Canada found the role or responsibilities of the most frequently given to facility management are as, maintenance and operations (91\%), facility planning (88\%), planning and management of public $(86 \%)$, design projects and manage the construction $(84 \%)$, energy management $(75 \%)$, environmental health and safety $(58 \%)$, property management $(56 \%)$, administrative $(52 \%)$ and information technology $(8 \%)$. In this regard, functions or role of this facility manager needs to be taken into account in determining the facility management competencies required in polytechnic so that it more effectively and efficiently in the success of the transformation plan in polytechnic in particular and government in general.

\section{Facility Management Chronology}

The term facility management or Facilities Management (FM) was first used in the United States at the end of the 1960s, which in the bank's practices in outsourcing in order to process card transactions to the expert (Scot, 1971) the existence of the Facility Management Institute in Ann Arbor, Michigan in 1979. The existence of the Institute is the result of efforts in the production of furniture Herman Miller. In the 1980s and early 1990s many facility management institutions that exist around the world as International FM Association (IFMA) in the United Kingdom, British Institute of FM (BIFM) in the United Kingdom, Europe FM (EuroFM) in Europe, FM Association (FMIA) in Australia, Japan Facilities Management Association (JFMA) in Japan, IFMA.

In this respect at the beginning of 1990, the field of facility management focus on issues of workplace and construction environment. While at the end of 1990 facility management began to prioritize as business functions (Norazlina, 2007). This indirectly gives an overview of facility management for the importance of a country. To see the contribution of facility management to a country, e.g. in Australia. In 2005-2006, the facility management industry in Australia directly contributed Australian Dollar 8.2 billion to the increase in value, $\$ 8.4$ billion to the gross domestic product (GDP) and full-time opportunities for 112,000 people. The above amounts represented $0.9 \%$ increase in value, $0.9 \%$ increase in GDP and $1.3 \%$ increase in employment opportunities for the whole Australian economy (Access Economics, 2007).

While indirectly, facility management contributed $\$ 5.4$ billion to the increase in value, $\$ 5.5$ billion to the GDP and employment for 68,000 people. In the event of combined contributions directly and indirectly, facility management industry accounted for $\$ 25.6$ billion to the increase in value, $\$ 25.9$ billion GDP and create job opportunities for 180,000 people. This combination makes $1.5 \%$ increase in value, $1.4 \%$ of GDP and $2.1 \%$ of jobs in Australia. This figure is a combination of facility management and facility management service provider (Access Economics, 2007).

Around the end of 1990 and early 2000 when the era of information technology and telecommunications took place all over the world, the role of facility management in the industry have diversifies. With the expansion of the facility management are making their debut in Asian countries such as Hong Kong, Japan, Korea, Taiwan, Singapore and Malaysia is no exception. For example in Hong Kong, facility management implemented since 1994 by the international facility management Association (IFMA), both local and from time to time this society is increasing its membership to successfully implemented an annual Conference (Syed et al., 2008). 


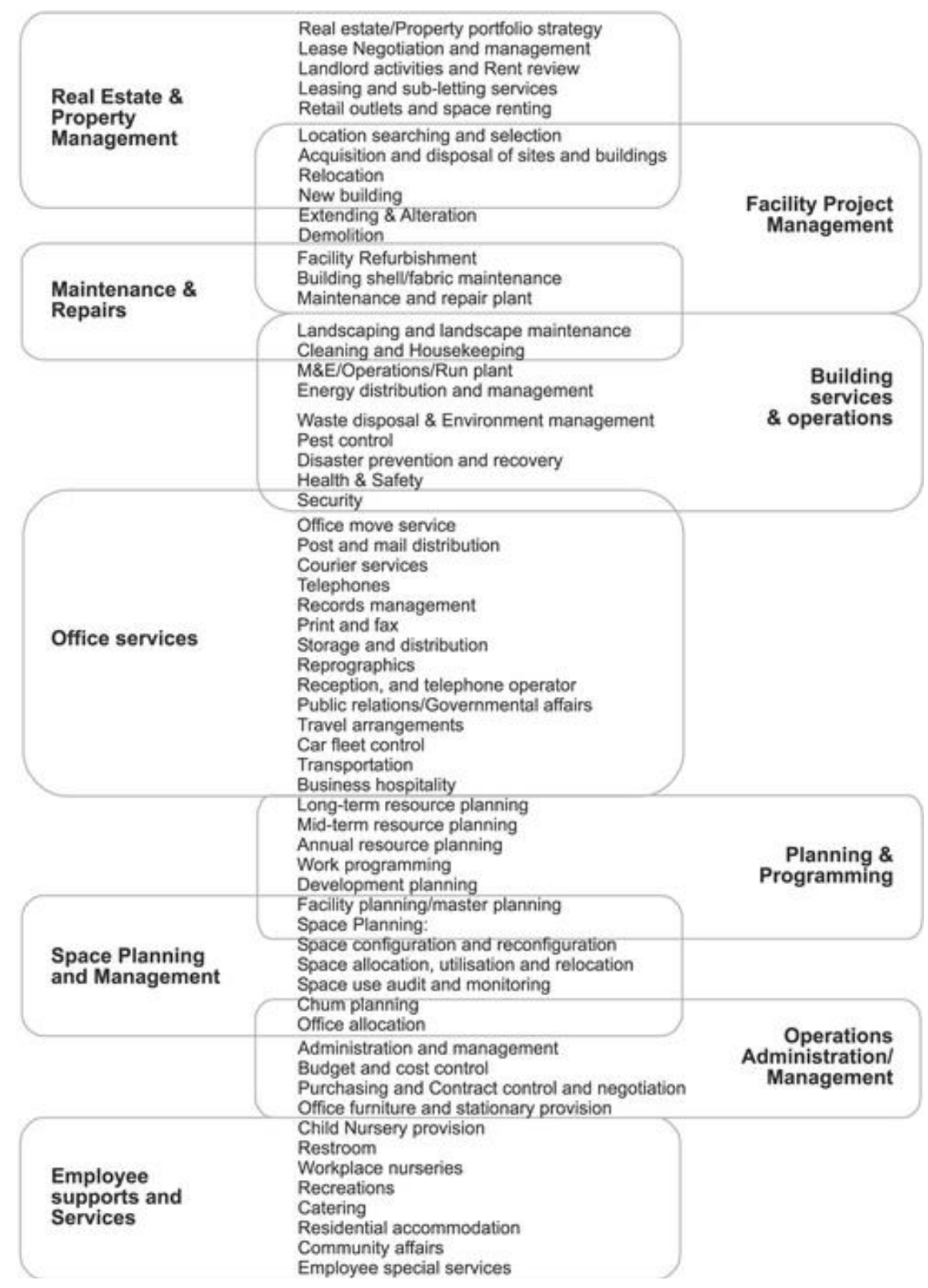

Figure 1 List of roles and responsibilities of facility management (Chotipanich, 2004)

While in Japan, most companies in the country of Sunrise undertook facility management in their organisation such as Nippon Telegraph and Telephone Headquarters Corporation when this company was the first to establish facility management system through automatic mechanism. According to Syed et al. (2008), Department of Industry and Trade of Korea reported $2.7 \%$ of companies that implement the concept of facility management. Even though this figure is low but most of the industry consists of a multinational corporation e.g. Samsung, Hewlett Packard and IBM Korea. Therefore, researchers are of the opinion that most large companies in Asia are aware of the importance of facility management in the organisation their business and to obtain the maximum returns.

\section{The Importance of Facility Management}

Facility management is a growing field at present and has been accepted by many countries around the world. In addition, this area is also relevant for an organisation whether in the public or private sector. As has been previously mentioned, facility management have a relationship between three things namely; workers, workplace and process. In this regard the importance of facility management in Malaysia has also identified as to:

1. Sustainable Environment and Function Facilities

Lately the phenomenon of building collapse (the power of one, 15 October 2010) and the ceiling collapse (New Sunday Times, 25 June 2010) and the middle ring MRR2 cracked flyover (new Sunday Times, August 4, 2008) increasingly threaten the public safety. There are many probable contributors to the phenomenon either our construction quality or lack of supervisory process 
during construction, deteriorated over years or lack of maintenance or lack of awareness process in the care facilities available (Prime Minister of Malaysia, 2007). In these problems who to blame for or become legally liable? In addition there are some instances, it happened to a project that has just been completed and involves government projects. Incident that contribute to loss of property and loss of life can be avoided if all relevant parties carry out their respective roles properly.

The Government has spent billion of dollars for enhancing the asset management industry and the country towards sustainable, by giving high value returns, risk-based and covers the entire life span of infrastructure construction. All the facility requires proper maintenance to ensure national facilities works well and achieves their maximum life cycle.

As such, in order to avoid incidents or unwanted incidents recurring and wasted public fund spending some cost for maintenance and implementation of facility management in an organisation, is deem necessary. With the implementation of facility management, namely, managing physical facilities as well as non-physical facilities as well as determining the need in investment or business. Facility management is necessary in achieving the investment or business by all services involved either directly or indirectly (Siti, 2009). Among the matters included in this field such as expert advice, preservation of buildings, renovation of buildings, building cleaning, parking, electrical systems, telephone, fire fighting systems, landscaping, air conditioning, rental agreement and etc., (Abdul Hakim et al., 2006).

\section{Promote Business Growth}

Apart from maintenance and maximum life cycle, the Government also emphasis on private and public partnership or Public Private Partnership (PPP) or Public Finance Initiative (PFI) where PPP is an exploration of new areas in facility management. PPP or outsourcing is a management method implemented in most organisations nowadays. This can be seen as reported in the Harvard Business Review in Corbett (2004) that the method of outsourcing is one of the form of idea of new management and many had implemented in this century. According to Martin (2006) outsourcing is a concept where the function in an organisation given to outside parties to manage them. In other words, it is a concept looking for expertise to conduct certain business functions outside of your own organisation (Abdul et al., 2006). To realise the significance of the facility management in business in Malaysia, in June 2010 the Government announced the strategy the "Tenth (10) Malaysia Plan", which was designed for national development journey towards achieving Vision 2020. Its main goal is to feature high income country. As a result of the new approach theme and the 10th Malaysia Plan formulated in the form of ten key ideas. Which ideas that support partnerships and effectively refers to private and public sharing of PPP is a strategy that can be implemented to overcome the lack of sources of financing and operation cost reduction.

In the $10^{\text {th }}$ Malaysia Plan, Malaysian Government allocates a sum of RM 20 billion (10 ${ }^{\text {th }}$ Malaysian Plan) to facilitate private sector investment in projects that have strategic value to the country and the multiplier effect through high on facilitation fund. The success of the PPP will be achieved if we practice these principles; principles of effective governance, depending on competitiveness and innovation to produce profitable returns values in both parties involved. The importance of PPP is also quoted by Pitt, Ali Hamsa, Alexander, Hamilton, Dombkins \& Ismail (Noor \& Pitt 2009) where PPP is the acquisition of innovative alternatives to determine return on investment financier. The PPP method can be realised through risk-sharing contracts, taking into account the whole life costing and payment based on performance. In this regard the role of facility management in Malaysia is very important in the success of the 10th Malaysia Plan to enable Malaysia to appear as a developed country and a high income nation.

\section{Human Capital Development}

In creating a facility management, an effective and efficient system of implementation of a service or product that is to be formed so that the quality of services and products can be delivered to customers quickly, smoothly and accurately. In this respect there are two key elements in this area, namely employees, staff or internal customers and external customers or users (Siti, 2009). Customer needs should be fully integrated into the design and development of services and products (Goldman, 2005).

Through facility management, individual and community awareness to the importance of the management of assets and facilities can be provided. In this regard the Government undertook a variety of activities to produce the human capital knowledge and competent as an asset management and Convention Facility in 2007 and 2009, the establishment of asset management Association and the Malaysian Project (MAPMA) and the Association of Facility Management (MAFM). With the implementation of these activities indirectly, individual knowledge and skills in particular and society in general would be improved and able to manage facilities effectively and efficiently. The Malaysian Government has also added a wider opportunity to cater the needs of the workforce in this field through educational programmes at Universiti Teknologi Malaysia and Universiti Teknologi MARA in the master level. This implies that significant of human capital development to produce a high income Nations and has a first class infrastructure in the world.

\section{Facility Management Implementation Initiatives In Malaysia}

General facility management in Malaysia associated with property management and maintenance management, but in fact both types of this management was different (Jasdy \& Judge, 2005). According to Pillay (2002), the development of facility management in Malaysia started in mid-1990. While in 1996, the Government began to privatise of non-clinical support services at government hospitals to three companies facility management practitioners (Syahrul \& Emma, 2009). This is the starting point for the era of facility management in Malaysia. In addition, during the opening ceremony Kuala Lumpur $21^{\text {st }}$ Convention and Exposition with reference to facility management in Malaysia, Abdullah (2010) stated that:

"If the people change the mentality to be a society that is more sensitive to the provision of better service and increased building care, then we who is a third world country that has a first class infrastructure development."

Malaysia began to stride forward in the development of facility management, especially in the public sector. Nowadays, the majority of the facility management practices carried out by the company property. This is because elevated building management is the 
responsibility of the property consultant. Table 4 lists of the premises that have been using the facility management of the computerised system.

Table 4 List of facilities using computerized facility management system (Syed et. al., 2008)

\begin{tabular}{|c|c|c|c|c|}
\hline No. & Category & Property & Facility System & Premise \\
\hline \multirow{3}{*}{1.} & \multirow{3}{*}{ Services / Facility } & Hospital & $\begin{array}{l}\text { THIS (Total Hospital Integrated } \\
\text { System) }\end{array}$ & $\begin{array}{l}\text { Selayang Hospital, Putrajaya } \\
\text { Hospital }\end{array}$ \\
\hline & & Warehouse & $\begin{array}{l}\text { CAFM (Computerized Aided } \\
\text { Facilities Management) }\end{array}$ & KLIA Cargo, MIMOS \\
\hline & & Hotel & BUS (Building Automation System) & $\begin{array}{l}\text { Hotel Pan Pacific KLIA, } \\
\text { Hotel Le Meridian }\end{array}$ \\
\hline 2. & Business & Office tower & BUS (Building Automation System) & $\begin{array}{l}\text { Petronas Twin Tower, Plaza } \\
\text { Central, Menara Telekom }\end{array}$ \\
\hline 3. & Commerce & Shopping complex & BUS (Building Automation System) & KLCC, KL Sentral \\
\hline 4. & Resident & Condominium & Smart Home System & KL Sentral, Cyberjaya \\
\hline
\end{tabular}

The Government has taken various initiatives to put Malaysia as one of the best countries that practice facility management in the world. Among the steps down the path is a Convention of National Assets and Facilities Management (NAFAM) in 2007 and 2009 , the creation of the policy, the involvement of the Construction Industry Development Board (CIDB), public works Department (JKR) and the Association of facility management (MAFM) as well as education.

1. Convention on the Management of National Assets and Facilities (NAFAM 2007 and 2009).

\section{a) NAFAM 2007}

NAFAM 2007 was held on 13 and 14 August 2007 at Putra World Trade Centre (PWTC), is a symbol of the Government's determination to establish comprehensive long-term plans to improve the management mechanism of assets and facilities. The Prime Minister of Malaysia, YAB Dato ' Seri Abdullah Ahmad Badawi said that the Government will set up a Special Committee to co-ordinate matters relating to the management of assets and facilities which will be led by the Chief Secretary.

In addition in NAFAM 2007, a memorandum of understanding was signed between Universiti Teknologi Malaysia (UTM) and the public works Department (PWD), agreed to establish cooperation between both the objectives of enhancing the competency of officers of the PWD officials in facility management. For the management of assets and facilities, NAFAM 2007 sets out a few things that need to be taken into consideration by the Government as;

- $\quad$ establish a monitoring system in terms of inventory and asset database, key performance indicators, benchmarking and reporting structure.

- $\quad$ upgrading of the procurement process through improvement of vendor selection criteria, good administration control and collaboration

- establishing financial model asset management and facilities ranging from the system into account - into account, the budget system, model cost calculation and control of expenses

- $\quad$ establishing a comprehensive competencies development through recognition, syllabus training and academic, public awareness campaigns, promoting the value of responsibility and ownership on the assets of the government and instilling a culture of maintenance

b) NAFAM 2009

The Convention was held on 26-27 October 2009, at PWTC Kuala Lumpur. In the Convention of YB Dato' Shaziman Bin Mansor, Minister of public works say that four key areas that should be given attention in facility management. First, ensure that facility management always prevail. Second, promote the comprehensive maintenance practices. Third, build capability and capacity and the last one taking into account the recovery in asset lifecycle.

Hence the Government has given strong support for the initiative to launch the Government asset management and policy manual in March 2009. To complement these efforts, as a national initiative, the Government through the Construction Industry Development Board (CIDB) has also developed a standards manual as a guideline to the owner of the assets in the private sector in facility management. Here clearly showed that the Government and private sector cooperation hand in hand in the success of the Government's dream to become the country with the most modern infrastructure.

2. $\quad$ Policy and Government Asset Management Manual

As a result of the NAFAM 2007 resolution the Government have decided for the Public Works Department (JKR) to be responsible for the preparation of guidelines of the management of assets and facilities in Malaysia. There are three guidelines which includes Governmental Assets Management Policy (DPAK), General Circular No. 1/209 and Comprehensive Asset Management Manual (MPAM). All these three guides were released on March 27, 2009. This is the first step in an attempt to use an asset management system that is more comprehensive and integrated. MPAM also explained the structure of the document and the essence of DPAK. The main reference in the DPAK is asset management practices (PAK) more systematic and effective.

In general, the structural hierarchy of government asset management document is composed of four (4) levels of documents, namely the document policies, manuals, procedures and supporting documents for comprehensive asset management (PAM) the Government as in Figure 2. 


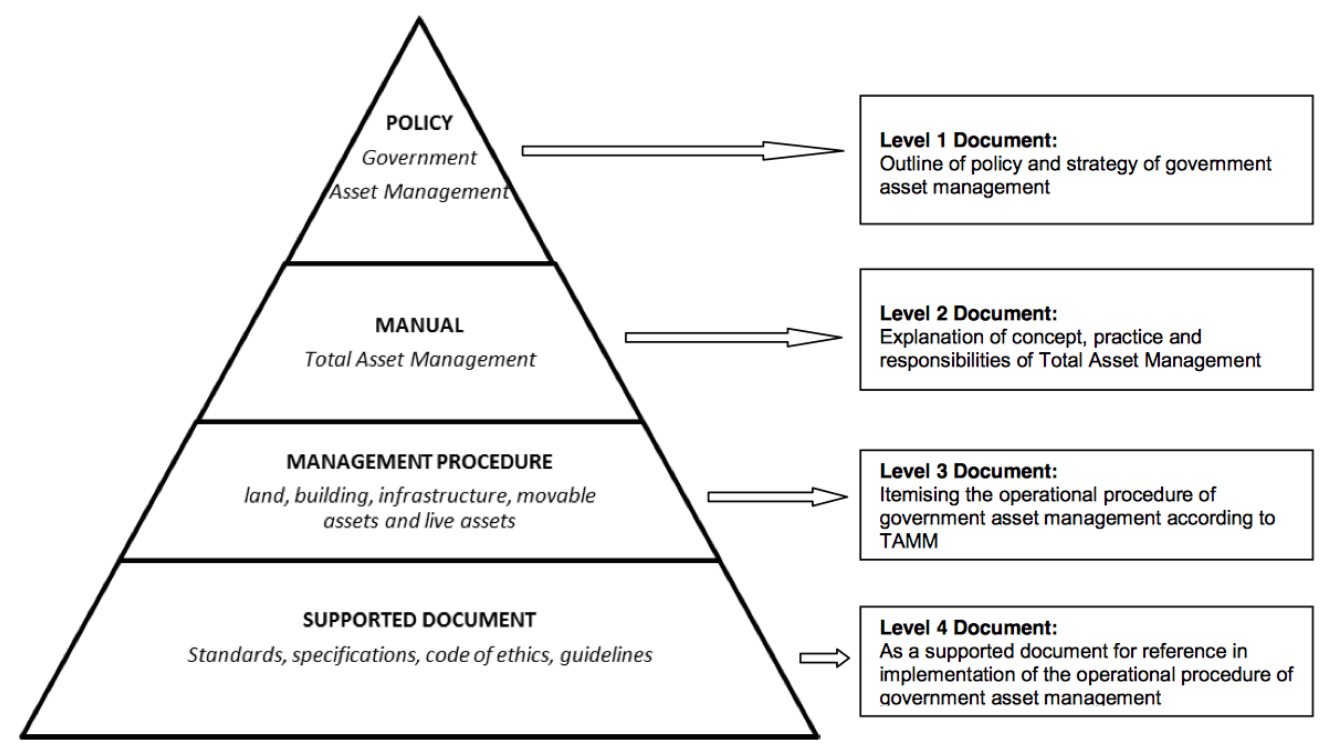

Figure 2 Government asset management document structure (Comprehensive Asset Management Manual, 2009)

While the DPAK outline roadmap, principles and strategies for the implementation of the asset management that must be complied by each agency. Four main objectives to be achieved through this policy namely;

- The creation of assets to meet the needs of government service delivery.

- Asset management carried out in a systematic, holistic and sustainable manner to achieve optimum asset interest.

- Systematic asset Information, integrity and easily reach.

- $\quad$ Comprehensive asset management practices implemented and monitored.

3. Construction Industry Development Board (CIDB)

- CIDB aims to develop, maintain and implement guidelines for facility management practitioners in Malaysia. The guidelines are in the form of manuals, policies, procedures and detailed procedures that will provide a clear definition of how facility management managed to complete successfully. Among its functions are; Promote and stimulate the development, improvement and expansion of the construction industry;

- Advise and make recommendations to the Federal Government and the State Government on matters affecting or relating to the construction industry;

- To promote, encourage and undertake research on any matters relating to the construction industry;

- To promote, encourage and assist export of services relating to the construction industry;

- Provide consultancy services and advice in respect of the construction industry; - Develop quality assurance in the construction industry;

- Revitalise the standardisation and improvement of construction techniques and building materials;

- Enable earned and maintain an information system of the construction industry;

- Convene, promote, review and coordinate training programs organized by the Center for public and private construction training for skilled construction workers and construction site supervisors;

- Accredited and register of contractors and to cancel, suspend or restore the registration of any registered contractor; and

- Accredited and certify skilled construction workers and site supervisors.

4. Facility Management Association of Malaysia (MAFM)

This system was established in January 2003 is intended as a catalyst for facility management industry in Malaysia. Currently MAFM is more focus on building awareness of facility management as a profession in the country. It is also a platform to interact, share information and start the approach best practices in facility management in Malaysia and other countries in the world.

5. Education

The education sector is also one of the Government's initiatives in the implementation of the facility management in Malaysia.There are now several institutions of higher education offering undergraduate programs for facility management to enhance the expertise and competency of staff in an organisation. Among the institutions directly involved are Universiti Teknologi Malaysia, Universiti Teknologi MARA. In addition there are several other institutions which also offer studies in research in the field of facility management such as University of Malaya, Universiti Kebangsaan Malaysia and Universiti Sains Malaysia. All this effort is to meet the needs of the labour market that is still low in Malaysia. 
Overall this paper presents clearly the current scenario and the important of facility management in Malaysia. No doubt the facility management industry is still new in Malaysia and requires huge support from all parties whether from the public or private sectors. Being a developing country that requires to compete with others in attracting investors in order to bring prosper to the country, providing and maintaining functioning and good working condition infrastructures is no nonsense. This is where the facility management play its role. In this globalisation era, the industry is very instrumental in the success of the Government's desire in realising high-income nation by 2020 also very much depending on facility management as investors will surely avoiding countries neither with insufficient infrastructure nor poor maintaining infrastructures.

\section{References}

Abdul Hakim, M. Maimunah, S. \& Maizan, B. (2006). Pengurusan Fasiliti. Edisi Pertama. Universiti Teknologi Malaysia.

Access Economics. (2007). Facilities Management Action Agenda (Managing The Built Environment). Third Year Implementation Report 2008.

Akta Perancang Bandar dan Desa, 1976 (Akta 172). Dewan Bahasa dan Pustaka. Kuala Lumpur.

Alexander, K. (1993). Facilities Management 1993 Centre for Facilities Management Strathclyde University. Hasting Hilton Publishing Ltd.

Alexander, K. (1996). Facilities Management European Practice 1996, Arko Uitgeverji bv, Nieuwegein, The Netherlands, 8(1),75-81.

Barrett, P., \& Baldry, D. (2003). Facilities Management: Towards Best Practice. Wiley-Blackwell.

BIFM. (2010). British Institute Of Facilities Management Web-Page, http://www.bifm.org.uk/bifm/home.

Centre for Facilities Management - CFM (1995). An Overview of The Facilities Management Industry Part III, Facilities Management and Hastings Hilton Publishers Ltd.

Cleland, D. I., \& H. Kerzner. (1985). A Project Management Dictionary Of Terms. Van Nostrand Reinhold.

Hamer, J. M. (1988). Facilities Management System. Von Nostrand Reinhold, New York.

Hishamuddin, M. A., Maizan, B. \& Dayang, S. A. S. (2005). Kualiti Perkhidmatan Fasiliti Hospital Kerajaan Dari Persepsi Pengunjung. Kes Kajian: Unit

Kecemasan dan Kemalangan, Hospital Kerajaan, Sarikei, Sarawak. REER Conference, Universiti Teknologi Malaysia, Kuala Lumpur (26-27 September 2005).

IFMA. (2010). International Facility Management Association. http://www.ifma.com.

Jamie, R. (2007). Where Will Facilities Management Be Five Years Time? BIFM Annual Conference. Oxford, London, United Kingdom.

Kamus Dewan (2005). Edisi Ketiga; Dewan Bahasa dan Pustaka. Kuala Lumpur

Kamus Oxford (2005). Dewan Bahasa dan Pustaka. Kuala Lumpur.

Noor, M. \& Pitt, M. (2009) A Critical Review On Innovation In Facilities Management Service Delivery. Facilities, 27, 211-228.

Norazlina, M.K. (2007). Emergent Trend of Malaysian Construction Industry: The Rise of Facilities Management. Universiti Teknologi Malaysia. Master Thesis.

Pesuruhjaya Penyemak Undang-Undang Malaysia. (2006). Akta Perancangan Bandar dan Desa, 1976. Akta 172. Undang-undang Malaysia. Percetakan Nasional Malaysia Berhad.

Pitt, M. \& Tucker, M. (2008). Performance Measurement In Facilities Management: Driving Innovation? Property Management, 26(4), $241-54$.

Price, I. F., Matzdorf, F., Smith, L., \& Agahi, H. (2003). The Impact of Facilities on Student Choice Of University. Facilities, 21(10), 212-222.

Scott, C. R., (1971). Why Facilities Management. Bankers Monthly, 88(10), 38.

Shaziman, M. (2009). National Asset and Facility Management (NAFAM) Convention 26, October, 2009. Kuala Lumpur.

Syahrul Nizam Kamaruzzaman \& Emma Marinie Ahmad Zawawi, (2010). Development of Facilities Management in Malaysia. Journal of Facilities Management, $8(1), 75-81$.

Wiggins, J. (2006). Training Tomorrow's Facilities Managers. Professional Qualification Facilities Management. http://www.mazefind.co.uk/ FMtutor/training_tomorrows_fm.pdf. 